\title{
Resource-Financed Infrastructure: Thoughts on Four Chinese-Financed Projects in Uganda
}

\author{
Tom Ogwang ${ }^{1,2}$ (D) and Frank Vanclay ${ }^{1, *(\mathbb{D})}$ \\ 1 Urban \& Regional Studies Institute, Faculty of Spatial Sciences, University of Groningen, \\ 9700AV Groningen, The Netherlands; ogwangtom@gmail.com \\ 2 Mbarara University of Science and Technology, P.O. Box 1410 Mbarara, Uganda \\ * Correspondence: frank.vanclay@rug.nl
}

Citation: Ogwang, T.; Vanclay, F. Resource-Financed Infrastructure: Thoughts on Four Chinese-Financed Projects in Uganda. Sustainability 2021, 13, 3259. https://doi.org/ $10.3390 /$ su13063259

Academic Editor: Guy M Robinson

Received: 7 February 2021

Accepted: 11 March 2021

Published: 16 March 2021

Publisher's Note: MDPI stays neutral with regard to jurisdictional claims in published maps and institutional affiliations.

Copyright: (C) 2021 by the authors. Licensee MDPI, Basel, Switzerland This article is an open access article distributed under the terms and conditions of the Creative Commons Attribution (CC BY) license (https:// creativecommons.org/licenses/by/ $4.0 /)$
Abstract: Increasingly common methods for financing public infrastructure in developing economies are Resources-for-Infrastructure (R4I) and Resource-Financed Infrastructure (RFI), usually involving Chinese financial institutions and Chinese construction companies. Although there are advantages to the borrowing country from these project financing arrangements, there are also various issues and governance challenges. In Uganda, expectations around future revenue from oil extraction have led to many infrastructure projects being commissioned, mostly funded by RFI arrangements. To consider the appropriateness of these arrangements and to reflect on whether they are likely to contribute to positive development outcomes or be examples of the resource curse, we examined four public infrastructure projects: Kampala-Entebbe Expressway; Karuma Hydroelectric Dam; Isimba Hydroelectric Dam; and the Malaba to Kampala section of the East Africa Standard Gauge Railway. Although R4I/RFI arrangements are viewed positively by some commentators, others (especially local companies) consider they lack transparency, create unsustainable debt, promote China's interests over the borrowing country, increase unemployment, unfairly compete with local business, deal in corruption, have poor working conditions, and result in substandard construction. Nevertheless, we conclude that Uganda and other developing countries have generally benefited from Chinesefunded infrastructure, and there is more myth trap than debt trap. However, to ensure positive development outcomes, governments and construction companies should ensure compliance with international standards, especially relating to: environmental and social impact assessment; human rights; benefit-sharing arrangements; livelihood restoration; and project-induced displacement and resettlement.

Keywords: China in Africa; China Exim Bank; international development finance; megaprojects; elite capture; extractive industries and society; environmental; social and governance issues; resource governance; Nigerian disease; China Belt and Road Initiative

\section{Introduction}

With the expectation of considerable revenue in the future from the exploitation of the oil reserves in Uganda's Albertine Graben region, there have been growing demands for the construction of public infrastructure in Uganda [1-5], requiring substantial funding that the Ugandan Government currently does not have [6]. To meet its infrastructure needs, Uganda needs to invest over USD \$1.4 billion annually, well into the future [7]. As with other resource-rich, cash-poor nations, Uganda is presented with a difficult choice: delay construction of desired infrastructure until resource revenues eventuate sometime in the future; borrow money now to build the infrastructure in the short term with the loans being repaid from and secured by future resource revenues, which is called resourcefinanced infrastructure (RFI); or enter into a resources-for-infrastructure (R4I) deal in which a foreign company (typically Chinese) builds the infrastructure now in exchange for natural resources (concessions, resource rights, or the actual commodities) into the future, with the 
country forfeiting some proportion of future resource earnings. We reflect on these options by analyzing four infrastructure projects in Uganda: the Kampala-Entebbe Expressway; the Karuma Hydroelectric Dam; the Isimba Hydroelectric Dam; and the Malaba to Kampala section of the East Africa Standard Gauge Railway. We describe the key aspects of these four cases, including funding arrangements, governance issues, and major concerns. Overall, we consider whether the institutional and financial arrangements around these four projects were in the best interests of the nation and its people, and we reflect on the appropriateness of RFI and R4I arrangements generally.

Public infrastructure refers to the wide range of facilities, public services, utilities and installations that are essential for the effective functioning of an economy and society [8]. It includes roads, bridges, railways, airports, public transport, telecommunications, sewerage, healthcare, education facilities, electricity and water supply, etc. To develop and achieve meaningful growth, developing countries must improve their essential public services and transport infrastructure [9-11]. There is a massive shortfall in funding for required infrastructure in African countries, estimated to total about USD \$50 billion per year [12]. Because of the deficit in infrastructure, about 645 million people in sub-Saharan Africa do not have access to electricity, and only one third of rural dwellers live within $2 \mathrm{~km}$ of paved roads [12]. The deficit is exacerbated by frequent disruptions to whatever services do exist. The infrastructure deficit and disruptions severely affect businesses, including local small-to-medium enterprises, and they retard job creation and other economic development activities $[13,14]$.

The demand for infrastructure, together with the availability of arguably competitive financing from Chinese banks, and competitive pricing and on-time, on-budget construction by Chinese firms, have led to much construction activity across Africa [12,15-17]. Some countries actively encourage foreign companies to invest, sometimes by offering favorable terms and conditions. Chinese firms have responded to these opportunities and have been building most of the infrastructure in Sub-Saharan Africa [18-21]. Furthermore, Chinese banks, especially the Export-Import Bank of China (China Exim Bank) [22] and the China Development Bank [23], have become significant financiers of infrastructure across Africa [24-28]. Chinese firms have benefited because most Chinese loans are tied to the procurement of Chinese goods and services [25]. These arrangements are a major concern to local industries in African countries. Chinese construction companies have also been successful in winning contracts through competitive bidding for infrastructure funded by the World Bank, the African Development Bank, and other lenders and aid agencies [25].

Many of the infrastructure projects being built in Africa are 'megaprojects' [29-32] in that they require considerable public funds to be invested (at least in the form of loan repayments) in highly complex projects that have financial arrangements comprehensible only to a few people [33]. Without effective governance and appropriate levels of capacity of government staff, the intended goals of these projects can become compromised, including by distorted project design, inflated pricing, poor quality construction, and project delays [33]. The appropriateness of the proposed projects (e.g., whether they are fit for purpose) also needs to be scrutinized.

The existing literature suggests that the governance challenges associated with infrastructure development projects include: a lack of transparency and accountability; a lack of respect for human rights; limited capacity to assess the risks and manage the issues associated with these projects; the presence of corruption; a lack of observance of the legal concept of the rule of law; restrictions on freedom of speech; and limited community engagement $[31,34,35]$. Some specific concerns include: the process used to select the construction companies (e.g., the use of no-bid or direct assignment contracts); an increase in national debt; inflated pricing; shoddy work by construction companies; and poor working conditions [36-40]. In our examination of four resource-financed infrastructure projects, we considered the extent to which these issues applied. 


\section{Defining Resources-for-Infrastructure and Resource-Financed Infrastructure}

The traditional approach to funding major public infrastructure in developing countries typically involved a national government securing a loan from an international financial institution (e.g., the World Bank or other multilateral development bank) or a private bank, and then commissioning an engineering/construction firm to complete the project. Now there is a wider array of project financing and construction models, some of which are tied to a country's mineral resources. Two terms tend to be used: resources-forinfrastructure (R4I) (sometimes called infrastructure-for-resources); and resource-financed infrastructure (RFI). The terms are related (and are sometimes interchanged), but they are different in that R4I means that the actual resources are promised to the lender, whereas in RFI, the income from the sale of resources is used to pay back a loan, with the resources providing the needed collateral (surety or backing) to secure the loan. Halland et al. [39] define RFI as "a financing model whereby a government pledges its future revenues from a resource development project to repay a loan used to fund construction of infrastructure" (p. 13). Conversely, an R4I deal or 'swap' can be characterized as an exchange of the actual natural resources for the construction of infrastructure, with the infrastructure being provided upfront and the resources being provided into the future $[21,25,40]$.

The precise arrangements in R4I/RFI deals vary and can be quite complex depending on the objectives of the resource-rich country and lender. For the lender nation, the objectives may include securing access to scarce resources, being part of a market-entry strategy (or new country entry), or securing an overseas market for firms in the lender nation. For the resource-rich country, the objective is usually about obtaining desired infrastructure earlier than would have been otherwise possible.

The general concept behind RFI and R4I first emerged in the 1980s under the guise of 'oil-backed lending', was often associated with Angola, and is sometimes called 'Angolamode deals' [25,39,41]. A particular feature of Angola-mode deals was that the lender made payments directly to the construction company, bypassing the government, thus reducing the potential for corruption. An example of this was a USD \$2 billion loan in 2004 from the China Exim Bank to finance reconstruction following the civil war in Angola. The loan was to be paid off by a commitment from Angola to provide China with 10,000 barrels of oil per day for 17 years. However, a further loan condition was that, for the 17 years of the agreement, at least $70 \%$ of all public tenders for infrastructure projects in Angola had to be awarded to Chinese construction firms [25]. This created many governance challenges, and raises the question of whether the arrangement was actually a good deal for Angola or not. R4I arrangements have also been implemented in the Democratic Republic of Congo, with similar concerns about whether or not it was a good deal [42,43].

Build-Own-Operate (BOO), Build-Operate-Transfer (BOT), Build-Own-Operate-Transfer (BOOT), Design-Build-Finance-Operate (DBFO) and other variations of Public-PrivatePartnerships (PPPs) are similar to RFI in that typically an external entity finances, designs and/or constructs the project, sometimes without direct payment. The company recoups its outlay either from the project itself-such as revenues from a tollway or electricity sales from a hydroelectric dam-or from annual payments from the government, or by some other arrangement. The financial arrangements for such projects sometimes include reduced taxation rates or free land. Other inducements might also be provided by governments to facilitate the private sector provision of socially-desirable infrastructure that would not be possible otherwise. Consequently, these projects are complex from financial, legal, governance and other perspectives [44]. While the various forms of PPPs are relatively self-explanatory, to give some sense of them, a BOT project, for example, can be described as:

a project based on the granting of a concession by a client (usually a public or governmental agency) to a consortium or concessionaire (usually in the private sector) who is required to 'Build' (including financing, design, managing project implementation, carrying out project procurement, as well as construction), 'Operate' (including managing and operating the facility or plant, carrying out maintenance etc., delivering product/service, 
and receiving payments to repay the financing and investment costs, and to make a margin of profit), and to 'Transfer' the facility or plant in operational condition and at no cost to the client at the end of the concession period. [45] (p. 196)

\section{Issues Associated with the Governance of Resources-for-Infrastructure (R4I) and Resource-Financed Infrastructure (RFI)}

Although many infrastructure projects are successfully completed, whether R4I/RFI or not, they are vulnerable to procurement irregularities (e.g., the direct appointment of contractors), distorted pricing (sometimes under-estimation of cost, other times overpricing), and elite capture (i.e., primarily serving the interests of certain groups rather than the wider public) $[46,47]$. The ex ante and ex post appraisal, assessment and evaluation of project arrangements are prone to systemic and systematic biases in the way evidence is collected and considered, and in how decisions are made [48]. Given the extent of clientelism and patronage-based decision making in Africa, capacity building and effective governance are essential if development initiatives are to achieve desirable social and development outcomes $[49,50]$.

The story about the alleged benefits of R4I/RFI arrangements relates to China's own experiences, especially its trade relationship with Japan in the 1970s [25]. Like African countries today, back then China was a poor, resource-rich country that lacked technology and infrastructure. In contrast, Japan was a rich, industrialized, resource-poor country, highly dependent on imported raw materials. Desperate as many African countries are today, at that time China was keen to import Japanese know-how and technology, for which it was happy to sell its vast coal reserves and crude oil. In 1978, the two governments signed a mutually-beneficial, long-term trade agreement worth over USD \$10 billion annually $[25,51]$.

Despite this positive interpretation of the background to R4I/RFI, there are three important differences between the current Sino-African arrangements and the Sino-Japan case that question the value of R4I/RFI for Africa. The first relates to technology transfer. In the Sino-African situation, there is limited technology transfer taking place because the infrastructure is being built by Chinese companies with only limited local involvement and no mechanism for technology transfer or capacity building. The second difference relates to financing. Japanese companies did not directly invest in China, however SinoAfrican relations revolve around financing from Chinese banks, one of which can offer state-supported discounted interest rates. The final difference relates to labor supply; in the Sino-Japan case, Japanese workers were not travelling in large numbers to China. However, many Sino-African deals have involved large numbers of Chinese workers going to Africa, and only limited use of local labor $[18,41,52]$.

China's presence in Africa partly relates to China's need for natural resources, its intention to expand markets for Chinese exports and professional services, its desire to contribute to world development, and is integral to its Belt and Road Initiative [53]. In contrast, African governments look to China to contribute to their economic development through aid, investment, construction of infrastructure, and to be a destination for their export products [54]. Obviously, as one of the world's largest economies and resource consumers, China needs to consider its access to resources in Africa as well as elsewhere [55-58]. By the early 2000s, China had already invested in most African countries [28], and it has now become a major provider of investment finance (see Table 1). Africa's trade with China has also grown considerably over the last two decades [21,59]. Thus, contrary to the negative statements made about R4I/RFI arrangements, the large number of African countries that have these agreements with China and the extent to which they are happy to be repeat customers provide evidence of the perceived value of these arrangements to the borrowing countries [18,53]. 
Table 1. Level of investment by China in various countries in Africa (top 20 countries).

\begin{tabular}{ccc}
\hline Country & Total Loans (Billion USD) & Number of Loans \\
\hline Angola & 43.2 & 256 \\
Ethiopia & 13.7 & 52 \\
Zambia & 9.7 & 69 \\
Kenya & 9.0 & 40 \\
Sudan & 6.8 & 68 \\
Nigeria & 6.2 & 16 \\
Cameroon & 5.9 & 44 \\
Republic of Congo & 5.1 & 29 \\
Egypt & 4.2 & 14 \\
Ghana & 3.7 & 37 \\
South Africa & 3.2 & 17 \\
Zimbabwe & 3.0 & 29 \\
Uganda & 2.9 & 14 \\
Cote d'Ivoire & 2.8 & 20 \\
Mozambique & 2.4 & 21 \\
Dem. Republic of Congo & 2.4 & 53 \\
Equatorial Guinea & 2.4 & 11 \\
Tanzania & 2.0 & 12 \\
Guinea & 2.0 & 14 \\
Senegal & 1.9 & 16
\end{tabular}

Source: China Africa Research Initiative https://chinaafricaloandata.org/ (accessed on 10 March 2021) [28] (data current as at 2018).

In cash-poor, resource-rich countries, natural resources tend to contribute to corruption, social unrest, poverty, and conflict, in other words, to the resource curse $[2-4,34,60]$. Some obvious examples of countries that have experienced the resource curse are Angola, Chad, Democratic Republic of Congo, Nigeria, and South Sudan [36]. R4I/RFI deals are used by Chinese companies to reduce the risks of doing business in countries with weak institutions, a lack of transparency, and low credit ratings [25]. There are many potential risks faced by companies and banks doing business in Africa, including the non-repayment of loans, nationalization of the project, and corruption in its many forms [61-64]. Arguably, R4I/RFI arrangements potentially reduce the probability and consequence of these risks [39]. A typical aspect of R4I/RFI deals is that the financial flows are managed by the Chinese not the host government, and are usually paid directly from the bank to the construction firm, thus bypassing the Ministry of Finance and avoiding possible leakage. This is in marked contrast to loans from the World Bank and other multilateral development banks, where payments are only made through the Ministry of Finance [65], potentially enabling syphoning-off, misdirection and embezzlement. Because of this, some scholars have argued that R4I/RFI deals are effective in limiting the risk of corruption $[25,36,66,67]$.

Despite all these arguments in favor of R4I/RFI deals, there are also some concerns. The soundness of a deal will depend on the precise terms and conditions of each specific loan agreement. In R4I deals, the price of the commodity in question into the future will also be a factor in assessing the ultimate value of the arrangement. It is possible that a proposed deal might not be favorable to the borrowing country and that it ultimately pays a higher effective interest rate than it would have if a conventional loan had been obtained (if one was available) [43]. Another issue of concern is the quality of the construction work undertaken by the Chinese construction companies. Halland et al. [39] considered that some infrastructure constructed through these deals was of poor quality and was poorly maintained. They suggested that some countries might find that the infrastructure built using R4I/RFI arrangements will have deteriorated to non-serviceable levels long before the repayment obligations had ceased. Another criticism that is sometimes made is that many projects funded by these arrangements are vanity projects that are not consistent with the country's real development needs [39]. There is also a concern relating to the 
perpetuation of African countries as sellers of unprocessed raw materials, which keeps them in a state of dependency and perpetuates neo-imperialism and neo-colonialism [68].

Because the financial arrangements typically require the use of Chinese contractors and inputs, this limits the ability of a country to use infrastructure development as an opportunity to develop in-country capacity and/or to reduce local unemployment. Another concern is that the cost of construction may not be competitive, given that borrowing governments are often more worried about their ability to access finance rather than about the project specifications or the total cost of the project [39]. Other concerns relate to the social impacts from the presence of large numbers of Chinese workers in African communities $[54,69,70]$. There are also concerns about the rights and working conditions of the Chinese workers themselves [71,72].

The serious issue of corruption in infrastructure development must also be addressed. Corruption is a political, legal and social issue, and greatly increases the cost to the public [73-75]. To ensure achievement of the intended economic, social and development objectives of projects and a fair business environment for all, it is essential to get infrastructure governance right $[47,76]$. This requires fighting corruption, and having a culture of accountability and transparency that is respected by all stakeholders, including the government, international and local businesses, and civil society [77].

\section{Methods}

This paper is part of a larger research project that considered whether the discovery of oil in Uganda is a blessing or a curse, and that examined the implications of oil discovery and extraction for the social and economic development of Uganda [1-4]. For the larger research project, a wide range of social research methods was used, including document analysis, field observations, key informant interviews, and focus groups.

The research design for the research in this paper was a multi-case case-study [78,79]. We examined four cases of resource-financed infrastructure in Uganda: the KampalaEntebbe Expressway; the Karuma Hydroelectric Dam; the Isimba Hydroelectric Dam; and the section of the East Africa Standard Gauge Railway from Malaba (on the border with Kenya) to Kampala (the capital of Uganda) (see Figure 1). These projects were at different stages of planning and implementation. As at early 2021, three projects had been funded by the China Exim Bank, with the Standard Gauge Railway yet to secure funding. The four projects were selected because, at the time our research commenced, they were the largest RFI projects being developed in Uganda. In our results section (Section 6), for each project, we briefly outline the potential benefits, harms and financing arrangements. In Section 7, we undertake a qualitative meta-analysis to consider whether, across the four cases, the financing arrangements were appropriate and effective from Uganda's perspective.

Consistent with case study research generally, we utilized a multi-methods approach, with triangulation in terms of sources and methods. However, since the purpose of this paper was to analyze the financial and institutional arrangements associated with each project, the primary research method used was document analysis. For each case, we accessed all available relevant documents, including parliamentary reports, government reports, NGO reports, and media statements. Of particular significance is that, for the three funded projects, we were able to access the project proposal document submitted to the Uganda Parliament for government approval of the loan. These project proposal documents detail the precise terms and conditions of each loan, state the official objectives of the project, and indicate other relevant issues. Media reporting about each project was also an important source of data. 


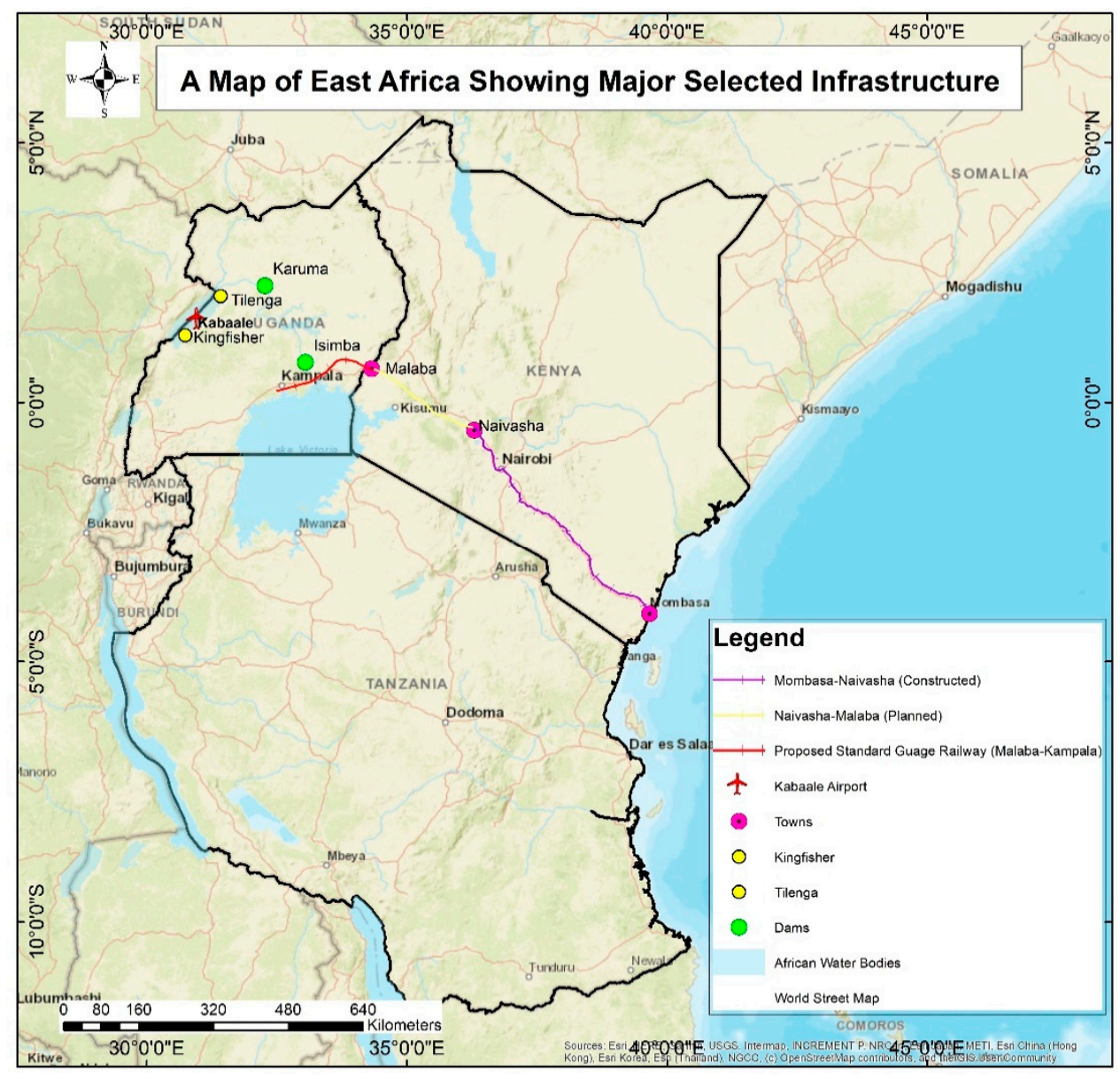

Figure 1. Map of East Africa showing the locations of the infrastructure discussed in this paper. (produced by Nuwagira Upton, Mbarara University of Science and Technology, Mbarara, Uganda).

In addition to the document analysis, we drew on 48 in-depth, key informant interviews undertaken in Uganda between October 2016 and March 2018. The interviews were with leaders at local and district levels, opinion leaders, and representatives of civil society organisations and the oil companies. The interviews were not necessarily case-specific, and were undertaken in a manner consistent with ethical social research [80].

\section{The Export-Import Bank of China}

The China Exim Bank was established in 1994 as a Chinese state-owned bank with the status of an independent legal entity. Under the control of the State Council, the bank assists Chinese policy on foreign trade, investment and international economic cooperation [81]. Because of their strategic function in promoting Chinese government interests, the China Exim Bank, the China Development Bank, and the Agricultural Development Bank of China are known as 'policy banks' [82].

The China Exim Bank is the only bank able to provide Chinese government-backed concessional loans, i.e., discounted loans where the Chinese government subsidizes the difference between a normal commercial interest rate and the discounted rate [83]. Arguably one of the world's largest development finance institutions [84], the China Exim Bank provides a wide range of banking services, including short, medium and long-term loans for foreign trade, export credit, import credit, offshore contracts, overseas investments, Chinese government concessional loans, and preferential export buyer's credit [81]. In 2015, China Exim Bank loans worldwide totaled CNY 1077.4 billion [82], which at the time was about USD $\$ 170$ billion. With its increased rate of lending in recent years, in terms of total 
lending, the China Exim Bank is now more-or-less equivalent to the World Bank. The China Development Bank had an even larger portfolio.

As at early 2021, the China Exim Bank was not yet a signatory to the Equator Principles, the sustainability and risk management framework for the world's financial institutions, although several other Chinese banks were. The English version of the China Exim Bank website [22] does not host the policy statements or environmental, social and governance performance standards that might normally be expected of a major bank [35]. A criticism of the China Exim Bank is that it is not transparent about its loans [85]. However, its English website does contain a White Paper on Green Finance [81], which articulates some of the procedures it uses, with mention of a 2007 document, Guiding Opinions on Environmental and Social Impact Assessment of Loan Projects, and a 2015 document, Green Credit Guidelines.

Scholars who have analyzed China Exim Bank's activities have generally found it does not intervene in the execution of the projects it has funded and does not ensure compliance with environmental and social performance standards, expecting this to be a matter for the host government and/or the construction firm [84-86]. A briefing paper [87] and research report [82] by the Beijing-based Global Environmental Institute carefully assessed China Exim Bank's environmental and social policies, comparing them to other international financial institutions. The Institute also found that, although the China Exim Bank generally requires environmental and social assessment, it usually accepts host country procedures, which may mean that some issues are not adequately addressed. However, they noted that the 2015 Green Credit Guidelines significantly strengthened the responsibilities to be taken by the Bank.

The types of loan offered by the China Exim Bank that have been used in Uganda include Export Buyer's Credit (EBC) and Preferential Export Buyer's Credit (PEBC). An Export Buyer's Credit is a commercial loan to an overseas borrower to facilitate the export (i.e., purchase by the borrower) of Chinese products, technologies and/or services (including infrastructure construction). EBCs are targeted to overseas financial institutions, finance ministries, institutions authorized by overseas governments, and overseas business owners and importers that are approved by the China Exim Bank [88]. The interest rate applied to an EBC varies, but typically is between about $2.0 \%$ (or 200 basis points) and $4.0 \%$ (i.e., 400 basis points) on top of LIBOR. LIBOR (the London Interbank Offered Rate) is the average interest rate banks borrow money from each other, and is, in effect, the cost of the money to the bank. LIBOR can vary widely depending on global trends. For example, between 2010 and 2019, LIBOR varied between about $1.0 \%$ and $3.0 \%$, but it exceeded $5 \%$ shortly before the 2008 global financial crisis. Because LIBOR does vary over time, there will always be uncertainty about future interest rates and loan repayment amounts. Before approving a loan, the bank assesses the risk, and ensures that country-specific risks are under control-in other words, that there is a sufficiently stable economic and political situation in the borrowing country [88]. The borrower is expected to have a good credit rating, and evidence of being able to repay the loan. A repayment guarantee (such as a sovereign guarantee or other instrument) and/or loan insurance may be required. Sometimes, the bank requires that the borrower establish an escrow account that must maintain a minimum balance of at least the next repayment amount and/or to which any income generated by the project must be deposited.

A Preferential Export Buyer's Credit refers to a medium to long-term loan with preferential terms and conditions, and is aimed at promoting China's trade and/or economic cooperation interests [89]. PEBC loans typically range from USD $\$ 100$ million to $\$ 1.0$ billion; usually at a fixed interest rate of $2 \%$ per annum; and a maturity date of up to 20 years. For PEBC and EBC loans, there typically is a 'grace period' of five years during which time no repayments need to be paid, although interest does accrue (strictly speaking in the finance world this is termed a 'moratorium'). Because PEBC loans are subsidized by the Chinese government, loan conditions are strict, requiring a signed contract with a Chinese contractor/exporter to be submitted as part of the loan application. Other application requirements include: a project feasibility report; environmental impact assessment re- 
port; information about the project owner; and information about the contractor, major subcontractors and suppliers [89].

Any fair assessment of the China Exim Bank has to conclude that it is not very different in purpose or procedure than the more than 100 export credit agencies around the world (other than China, the largest of which are the USA, UK, France, Germany, India, Italy and South Korea). However, an important point of consideration is that China Exim Bank loans are normally denominated in Chinese Yuan (CNY), even though US dollar amounts are usually mentioned in loan documentation. Therefore, future loan repayments will be vulnerable to any exchange rate fluctuations. Although predicting the future is always fraught, it is quite likely that the $\mathrm{CNY}$ will strengthen over time, especially compared to the borrowing countries, thus making repayments more expensive in the future than they were when the loan was established.

\section{Four Case Studies of Resource-Financed Infrastructure Projects in Uganda \\ 6.1. Case 1: The Kampala-Entebbe Expressway}

The Kampala-Entebbe Expressway is a $51 \mathrm{~km}$, four-lane, dual-carriage toll-road linking Kampala to Entebbe Airport. The stated intention of the expressway was to: "(a) Reduce congestion and increase the commercial viability of Greater Kampala Metropolitan area; (b) Improve mobility, reduce travel times, vehicle operating costs and accident rates; and, (c) Provide better access to local facilities for communities, creation of employment and increase in value for land and properties along the area of influence" [90]. Construction of the expressway commenced in 2012 and it opened for use in June 2018. However, a delay in updating legislation meant that no toll could be charged until the new Road Act came into force (which only happened in December 2019). Then there was a delay in selecting a toll operator, which only was announced in February 2021, so no toll was collected until some time in 2021.

The idea to have an expressway to the airport had existed for many years, but could not progress until financing was available. Eventually in 2011, a USD \$350 million PEBC loan was acquired from the China Exim Bank. A requirement of the loan was that the project had to be constructed by a Chinese company, and the state-owned China Communication Construction Company was chosen. All payments from the Exim Bank were made directly to the contractor. The loan is repayable over a 20 -year period, with a fixed annual interest rate of $2.0 \%$ (applicable to disbursed and non-disbursed funds). Following a grace period, the first loan repayment was due in July 2019 [91].

Apart from the loan, there were management fees and commitment fees that had to be paid. The government also had to contribute USD \$126 million towards construction costs and $\$ 40$ million to compensate displaced landowners along the route. Overall, the cost of the highway was approximately $\$ 2.5$ million per lane $\mathrm{km}$, which, despite local media reports that it was amongst the most expensive roads in the world [92,93], is not inconsistent with current costs of highway construction, especially when the engineering issues and geological conditions of the route are considered.

The loan agreement required that the government make 26 bi-annual repayments of USD \$13.4 million each commencing on 21 July 2019 (running through to January 2032). The government initially argued it would repay the loan from revenue raised from tolls. However, this is problematic because it would be impossible for the expected volume of traffic to generate this amount of money (over USD \$73,000 per day). Furthermore, there was a delay in updating the legislation to allow collection of a toll, and a delay in appointing a toll collection company. Consequently, from June 2018 to sometime in 2021, no toll was collected. The precise reason for the delay in updating the legislation is unclear, but likely to be at least partly related to the fact that the Ugandan Parliament spent much time debating a proposal to remove restrictions on the maximum age of a President. The proposal, which was eventually passed in December 2017, was to allow the then 73-year-old Museveni, who had been President since 1986, to contest yet another term in office. Museveni was returned as President in the January 2021 election, although 
somewhat controversially. The Road Bill (which enabled the charging of tolls) was eventually approved by Parliament in May 2019, but was not signed into law by the President until October 2019. However, then there was a delay in selecting a contractor to collect and manage the tolling arrangements, with the French company, Egis, being appointed in February 2021.

In April 2019, a senior government official announced that Uganda could not afford to make the first repayment on the loan, which was due on 21 July 2019, because no provision for this had been made in the national budget [94]. The official noted that there was an oversight on the part of the Ministry at the time of acquiring the loan, which meant that the government gave no thought about how to make the loan repayments or to schedule them into national budget planning. This oversight is indicative of the governance challenges related to infrastructure projects in developing countries [16]. An issue arising from having failed to plan for the repayments is that, to meet the shortfall, the government will need to borrow further or re-allocate already designated funding, which will likely deprive citizens of services, like healthcare or education.

The expressway has reduced travel time for the journey between Kampala and the airport from the previous two to three hours depending on traffic, to under an hour. This reduced journey time will likely persist long into the future. However, despite the lack of a toll, traffic volumes are well below the expected numbers. It is thought that the few entry points to the expressway reduces its functionality, and, although the expressway itself is good, the entry points are not easy to reach, thus many people continue to use their established routes instead of the expressway. Given its limited use, there is no evidence that the expressway has achieved its objectives to reduce congestion, increase the commercial viability of the Kampala Central Business District, improve mobility and access, or reduce accidents. In fact, the expressway has increased the number of speed-related accidents in Uganda, including one involving the Kampala Mayor [95]. In response to the number of accidents, there is now a high level of police presence on the expressway, displacing them from other duties. Quite likely, the project has primarily benefited only some groups in society (e.g., those who make frequent trips to the airport), while providing limited or no benefit to the majority of the population, at least in the short term. Thus, it is doubtful that the road was an effective addition to national infrastructure or to development in Uganda.

\subsection{Case 2: The Karuma Hydroelectric Dam}

The Karuma Hydroelectric Dam is a $600 \mathrm{MW}$ dam financed by the China Exim Bank being constructed by Sinohydro, and now expected to come online in 2021. Located on the Victoria Nile in the northwest of Uganda, it is one of the largest dams in Africa. It has a long controversial history, which is intertwined with the also controversial Bujagali Dam [96]. Although securing financing was initially difficult and there were many issues to address, the considerable need to increase electricity generation capacity meant that the Government of Uganda remained strongly committed to the Karuma project and initiated land clearing for the dam in 2012. With an agreement in principle to fund the project being reached between President Museveni and President Xi Jinping in March 2013, construction started in 2013. The total cost was determined to be approximately USD $\$ 1.7$ billion, of which $85 \%$ (\$1.4 billion) was borrowed from the China Exim Bank, and the Government of Uganda contributing \$253 million (15\%). An advance payment guarantee was given in June 2014 to allow Sinohydro to start work, a memorandum of understanding was signed in September 2014, although the formal loan agreement was not finalized until mid 2015. Apparently, Uganda had problems supplying the necessary documentation and in establishing an escrow account [97]. Ultimately, there were two components to the financing package: an EBC of $\$ 645,821,407$ and a PEBC of $\$ 789,337,275$ [98]. The initial completion date was December 2018, however various delays led to this being changed to December 2019, and then to December 2020. The most recent news (November 2020) suggests it will still be another 6 months or so before the dam is operational. As it is now over 5 years from when the loan was approved, the grace period (for the PEBC part of the loan) has expired 
and the first repayment was due before the dam was completed and before any income or electricity had been generated.

The PEBC component was a loan of USD $\$ 789$ million, for a term of 20 years, including a grace period of five years. The interest rate was fixed at $2 \%$ per annum. There was a once-off management fee of $0.25 \%$ of the loan, and a commitment fee of $0.25 \%$ on any undisbursed but available amounts each year. The EBC component had various conditions including: the repayment period would be 15 years commencing on the day the dam was fully commissioned; the interest rate would be LIBOR $+3.5 \%$ per annum; a onceoff management fee of $0.5 \%$ of the loan; a commitment fee of $0.5 \%$ per annum on any undisbursed but available amount; loan insurance cover had to be obtained from the China Export and Credit Insurance Corporation (SINOSURE) amounting to around USD $\$ 65$ million for total loan period [98]. Another requirement was a Repayment Reserve Account with the China Exim Bank, which, for the first few years of the loan, would have to maintain a balance of at least the amount needed to pay the next repayment. The standard application procedures also required: a signed contract with Chinese contractors; a project feasibility report; an environmental impact assessment report; information about the project owner; and information about the contractor and major subcontractors and suppliers [89].

The Parliamentary Committee Report on National Economy observed that the conditions of this loan package were not particularly favourable and recommended that the Uganda Government always examine alternative sources of finance rather than continually borrow from the same source [98]. The complexity of the loan conditions raises issues about the capacity and competence of all relevant actors and about the accountability, transparency and governance surrounding the loans. The report contradicted the perception that Chinese loans were cheaper compared to other lenders and had 'no strings attached', as claimed by many African leaders including Museveni $[99,100]$.

Similar to Chinese-funded projects elsewhere, there have been questions about the bidding process, contractor selection, procurement issues, and the quality of work. Although an official procurement process was initiated, it was subsequently bypassed, with Sinohydro being directly awarded the tender [98,101]. Although Sinohydro had been among three prequalified bidders, it was not invited to tender because the Contracts Committee of the Ministry of Energy and Mineral Development considered it did not provide sufficient information regarding the roles and responsibilities of all partners in the project. The Contracts Committee indicated that China International Water and Electric Corporation (CWE) was the preferred bidder. Nevertheless, a Presidential Directive ordered that Sinohydro be appointed and the normal procurement procedure was cancelled. The President justified his action simply by stating that his advisors had recommended Sinohydro [102].

A Memorandum of Understanding for construction of the dam and associated transmission line was signed between Sinohydro and the Ministry of Energy and Mineral Development in June 2013. On the same day, CWE wrote to the Ministry threatening to take legal action in relation to irregularities in the procurement process. Legal action was abated by CWE being given the contract to build the Isimba Dam (see Case 3).

It is not clear why the President ordered that Sinohydro be given the Karuma project. The Chinese Government only required that the Government of Uganda choose any Chinese company and allowed the Uganda Government to decide which company to select. Amidst much civic unrest about Museveni's action, one Minister stated that Uganda's procurement laws allowed for direct arrangements, such as those negotiated by the President. Another Minister argued that "the public had lost faith in the procurement process because of endless allegations and court injunctions" and that it was time to take action [102]. Museveni had often intervened in bureaucratic processes to ensure quick outcomes and was known as being a man of action $[50,96,103]$. He had stated several times that the World Bank interfered too much, held neo-colonial values, and did not understand the consequences of structural adjustment in countries without an adequate electricity supply [100].

Uganda was (and arguably still is) amongst the countries in the world with least access to electricity. In 1992 (early in Museveni's rule), less than 1\% of the population had 
electricity. In 2006, when commercial oil was discovered, less than $15 \%$ had electricity. By 2015, it was around 20\%, but reached nearly 50\% in 2018 [104]. Increasing access to electricity has required improved distribution systems and increased supply. A secure electricity supply is also required for the East African Crude Oil Pipeline, which is needed to transport Uganda's oil to world markets [4]. With a limited electricity supply being a barrier to development, it is understandable that a progress-minded government would prioritize electricity generation. However, such an objective does not necessarily indicate that the Karuma Hydroelectric Dam itself was an effective project, that the financing arrangements were appropriate, or that the work would be undertaken to adequate standards.

\subsection{Case 3: The Isimba Hydroelectric Dam}

The 183 MW Isimba Hydroelectric Dam project commenced construction in April 2015 and became operational in March 2019. Following the objection regarding the contracting process for the Karuma Dam (Case 2), the China International Water and Electric Corporation (CWE) was directly awarded the contract to build the Isimba project in a Presidential Directive dated 24 July 2013. The project comprised construction of the Isimba Dam and power station, a $132 \mathrm{kv}$ substation, and the $41 \mathrm{~km}$ Isimba-Bujagali transmission line. The total cost of these projects was USD $\$ 568$ million, of which $85 \%$ (\$482 million) was funded by a PEBC loan from the China Exim Bank, with the balance ( $\$ 86$ million) being provided by the Government of Uganda [105]. Given that China Exim Bank's PEBC application procedures require a signed commercial contract to be included, a Memorandum of Understanding between the Government of Uganda and CWE was signed on 22 July 2013 to secure funding [105]. The loan was awarded in 2014.

The loan had a fixed interest of $2 \%$ per annum. A once-off management fee of $0.25 \%$ (USD \$1.21 million) and commitment fees of 0.25\% (\$1.35 million) were due in the first year of the loan. The government had to establish an escrow account in a commercial bank (potentially in Uganda) that was acceptable to Exim Bank to which all revenues generated by the project (i.e., electricity sales) must be deposited. The government had to ensure that a Power Purchase Agreement (on 'take or pay' basis) was concluded with the electricity distribution companies. Any shortfall in the revenue needed to repay the loan must be met by the government. The government was also required to ensure that the unresolved land acquisition and resettlement issues associated with the Isimba-Bujagali Interconnection Line were resolved before the project was implemented. Finally, the government was required to submit all appropriate financial reports to the China Exim Bank [105].

There was criticism of shoddy work in the construction of this dam. Some critics argued that the cost (approximately USD \$568 million or \$3.1 million per MW) was excessive [106]. There were concerns about changes away from the approved design and disregard of the advice of a panel of experts about how to fix some problems, specifically cracks in the dam wall. During one site inspection, the inspection team found that CWE did not have a technical engineer on site to supervise repairs. It was feared that the absence of senior technical staff compromised the integrity of the dam; reduced the ability of the dam to produce electricity; and could result in a dam that was below specification [106]. CWE was accused of ignoring correspondence from regulatory officials, making alterations without approval, not keeping the Government of Uganda informed, and shoddy work:

The most troubling shoddy works at Isimba can be seen with the equipment that will form the gates of the dams, which will control the water flow. The gates are important because they allow how much water can be channeled into the turbines, where the electricity will be produced. For example, the rollers on the gates are carbon steel, and yet what appears to have been agreed in the bill of quantities was stainless steel. The same can be said of the cylinders, a critical component of the gates. Other sloppy works were noticed with the cut-off wall, a structure that is supposed to reduce any water seepages into the dam. [106] (online)

The Government of Uganda and CWE had agreed that stainless steel would be used. However, CWE ultimately installed cheaper ceramic-coated parts. This may mean that 
the facility will deteriorate quickly and need replacement in a shorter time than would otherwise be expected [106]. Although a senior government official in the Ministry of Energy and Mineral Development we interviewed dismissed these concerns as being unsubstantiated allegations without any merit, it is evident that there have been concerns about the dam's technical integrity and the legitimacy of the project. As with the Karuma Dam, there was no open bidding process for the construction of the Isimba Dam. Because of governance and oversight failures, proper procedures were not followed, and the dam was not constructed according to the original specifications. This suggests that more funding may be needed to rectify these problems in the future $[107,108]$.

\subsection{Case 4: The Standard Gauge Railway from Kampala to Malaba}

The East Africa Standard Gauge Railway project is a grand master plan that intends to link various countries in East Africa by rail to Mombasa, a major seaport in Kenya. The total cost of all sections together will be in the order of tens of billions of dollars. It is called 'standard gauge' because it is being constructed according to the international railway standard of $1435 \mathrm{~mm}$ (historically $4 \mathrm{ft} 8 \frac{1}{2}$ inches) rather than the colonial one metre narrow gauge that has been used in much of Africa. The idea is to move freight containers by rail rather than road, as is currently the case. This will reduce the cost and time taken for the transportation of goods and will also reduce the road death toll, which is very high in most African countries. Passenger trains will increase accessibility and the convenience of travel. To give an idea of the expected benefits, the cost of delivery of a 40 foot shipping container from Mombasa to Kampala is likely to go from the current USD \$3500 down to $\$ 1500$, and from the current 10 or so days down to just 2 days [109].

In May 2017, Kenya opened the first leg of the railway line (some $472 \mathrm{~km}$ ) linking the port of Mombasa to Nairobi, costing USD $\$ 3.2$ billion, which was borrowed from the China Exim Bank. After Kenya secured a second loan (USD \$1.5 billion loan) from the China Exim Bank in May 2017, the $120 \mathrm{~km}$ Nairobi to Naivasha section was completed in October 2019. It is hoped that the network will continue from Naivasha to Malaba (on the Kenya-Uganda border), and then be extended within Uganda, and eventually to the neighbouring countries of South Sudan, Rwanda, Burundi, and the Democratic Republic of Congo. Within Uganda, four sections of the Standard Gauge Railway are planned, costing an estimated total of USD $\$ 12.8$ billion. The primary section connects Malaba (on the border with Kenya) with the capital city, Kampala. However, for that to be viable, a critical component is the yet-to-be constructed $375 \mathrm{~km}$ section in Kenya between Naivasha and Malaba.

The original idea was that the $273 \mathrm{~km}$ section from Kampala to Malaba would be built contemporaneously with track construction in Kenya. Estimated to cost USD \$2.3 billion, the Kampala to Malaba section was initially intended to have been completed in 2018 . However, this date has frequently been revised because Uganda has failed several times to secure financing, and there have been many other issues. Nevertheless, much land acquisition for the railway line has taken place. With a $60 \mathrm{~m}$ wide corridor being required, over 3000 people have been displaced, and 33 schools and 11 factories have been affected [110]. In March 2020, after yet another loan rejection, Uganda still remains committed to the project and claims to be in ongoing discussion with the China Exim Bank [111]. The Bank has required that, before it would approve any loan, the Uganda Government must secure a guarantee that Kenya will complete the Naivasha to Malaba section, something that is in doubt [112]. The Bank has also demanded that the Ugandan Government adequately compensate all project-affected persons, amounting to some USD \$90 million. Another condition was that a study of the financial viability (i.e., business case) of the project had to be conducted. The Bank is concerned about whether construction of the railway makes real business sense and about Uganda's ability to meet its repayment obligations [113]. It is important to note that the China Exim Bank has not yet approved the loan to Kenya for the Naivasha to Malaba section [114]. 
Despite a favourable view of the project by some people, there have also been detractors. The first two sections of the railway line in Kenya, from Mombasa to Nairobi, and then to Naivasha, created much controversy [114]. In Uganda, there have been complaints about the estimated cost of construction. For example, after visiting rail projects in Ethiopia and Djibouti, and noting that the costs of Uganda sections were much higher, a Ugandan parliamentary committee demanded a review of the proposed project. The Ethiopia-Djibouti line, which opened in October 2016, cost USD \$3.4 billion for $656 \mathrm{~km}$ ( $\$ 5.18$ million per $\mathrm{km}$ ), while the Ugandan leg of $273 \mathrm{~km}$ will cost $\$ 2.3$ billion ( $\$ 8.4$ million per $\mathrm{km}$ ). Kenya's $472 \mathrm{~km}$ stretch cost $\$ 3.4$ billion ( $\$ 7.2$ million per $\mathrm{km}$ ) $[115,116]$. In 2017 , the Ministry of Transport [117] produced a factsheet to explain why the cost structure was higher in Uganda, explaining that: $53 \mathrm{~km}$ of swampy ground had to be traversed; many bridges were required, including a $939 \mathrm{~m}$ bridge across the Nile River; and that most input costs were higher because of higher transport costs in Uganda. By way of comparison, a PWC report written for the European Commission [118] suggested that the typical cost of new conventional railway construction in Europe was $€ 8$ million per $\mathrm{km}$, although there were many variables and additional items to consider. Nevertheless, this does establish that the costs in Uganda, and East Africa generally, are not inconsistent with costs around the world.

Although Uganda is persisting with its desire to proceed with the Standard Gauge Railway, the China Exim Bank is ensuring that this project is a worthwhile investment and is setting requirements that are similar to the normal conditionalities that most traditional lenders would typically apply. Proper compensation of project-affected persons is an essential requirement of all project financing $[4,10,32,35]$. A 'bankable feasibility study' is a normal expectation in project development. The fact that the China Exim Bank has declined loan applications by Uganda and Kenya is proof that they are exercising appropriate oversight and not just funding any ill-considered loan request. Superficially, the Standard Gauge Railway seems to be desirable infrastructure, but closer examination indicates it is a real megaproject, replete with the seven Cs $[32,114,119]$ : colossal in size and scope; captivating because of its size, design or engineering achievements; costly in construction and in that costs are typically underestimated; controversial, attracting much public protest; complex in terms of high risk and uncertainty; laden with control issues related to confusion over responsibilities and who manages, operates, or regulates them, as well as potential interference by various stakeholders; and prone to corruption.

\section{Discussion: Is Chinese Finance in Africa Debt Trap or Myth Trap}

As is evident from our review of the literature and from the four cases we considered, China is a major player in Uganda and Africa generally. Many commentators have raised concerns about China's expanding economic presence in Africa. They have warned about a lack of transparency, the hiring of Chinese instead of local workers, the creation of unsustainable debt, the promotion of China's commercial interests ahead of the borrowing country's needs, and a lack of good governance [36-40]. As discussed in this paper and elsewhere [120-122], it is likely that there is little truth and much myth-making and fearmongering in these allegations. There certainly is no evidence of any overly zealous attempt by Chinese companies or banks to push unwanted projects onto Uganda or other African countries. But this does not mean that there should be no questioning of the appropriateness of the arrangements or the projects themselves.

A major concern of many commentators is increasing national debt. As at mid 2019, external debt in Uganda was USD $\$ 8.3$ billion (not including undisbursed amounts), about $43 \%$ of its GDP [123]. By world standards [124], this is not high, and perhaps more important are the interest rates that apply, the potential for unfavorable exchange rate fluctuations, and the development potential of the projects for which the money was being borrowed. A 2018 Ministry of Finance, Planning and Economic Development report [125] indicated that Uganda's debt to the International Development Association (the part of the World Bank that provides concessional loans to the world's poorest countries) was $40 \%$ of 
Uganda's total debt, followed by China Exim Bank (22\%), and the African Development Bank (17\%). The Ugandan Parliamentary Budget Committee has raised concern about the extent of government borrowing, arguing that it is beyond Uganda's means, especially given that debt repayments exceed all other budget items together [126]. The Bank of Uganda has warned that, should there be an exchange rate depreciation or slow growth in government revenue, such as a delay to first oil, there would be a high likelihood of inability to meet debt obligations. The Bank also indicated that a high debt burden could slow economic growth in Uganda because of deferred government investment in other socially-desirable projects.

If the desired loans for the Standard Gauge Railway and other planned projects are approved, Uganda's debt will more-than-double. The Government sought loans for the projects discussed in this paper in the expectation that future oil revenue would guarantee and / or service the loans. The risk to Uganda (and to the China Exim Bank in relation to possible loan default) depends on the viability of the projects as well as the certainty of oil revenue, especially in the short term when the grace period expires and repayment obligations commence. A complicating issue is that Uganda's tax base is small and, with few alternative sources of revenue, should there be a delay in oil production, stoppages in the future, or a reduction in the oil price and thus revenue to Uganda, the government will find it difficult to make the repayments. Uganda has a poor debt repayment history and has previously benefited from debt relief under the World Bank and International Monetary Fund's Heavily Indebted Poor Countries (HIPC) initiative in 1998, the Enhanced HIPC scheme in 2000, and the Multilateral Debt Relief Initiative in 2006. Nevertheless, Uganda is now considered to be a good credit risk due to its oil reserves, which are forecast to net Uganda around USD $\$ 43$ billion over the next 25 years [127].

The Karuma and Isimba dam projects have come under scrutiny because of alleged substandard work, procurement irregularities, allegations of bribes and kickbacks, employee welfare issues, and lack of local content $[107,108,128]$. Some critics say the projects were 'dammed' from the beginning given that the President directly engaged Sinohydro for Karuma and CWE for Isimba [92]. Without a competitive bidding process, there is a risk of reduced value for money [21]. It is important to realize that corruption, opportunism, elite capture, and a lack of transparency are not limited to R4I/RFI transactions, and frequently arise in all resource and infrastructure projects $[39,73]$.

One criticism of Chinese loans relates to their cost [129]. Twinoburyo [92] argued that, despite apparently low interest rates, Chinese project loans are actually expensive, doubleedged relationships. Most construction materials must be imported from China even when they can be procured locally at a cheaper price $[37,130]$. Brautigam and Gallagher [72] advocated that African countries should insist on greater levels of local procurement.

While some critics assert that China is putting Africa into a debt trap, China's position is that it is helping Africa develop, not accumulate debt, and it has denied any 'debt-trap diplomacy' [120,122]. China's Special Envoy for Africa has argued that China was not the main creditor of most highly-indebted African countries and that it was inappropriate to blame China for Africa's debt problems [131]. The Envoy also observed that many factors contribute to reduced income from exported raw materials, and suggested that African countries should seek to export value-added products. A counter argument might be that many African countries suffer from structural problems such as poor infrastructure, limited power supply, and poor technology, which prevent them from transforming raw materials into finished products. Furthermore, many countries have liberalized their economies to make them attractive locations for multinational companies, which has led to many local businesses becoming uncompetitive.

\section{Conclusion}

Given the high demand for infrastructure in Sub-Saharan Africa, the availability of Chinese finance, and China's desire to support its companies to access markets around the world, it is likely that China will continue to invest in worthy projects in Africa and 
elsewhere. Although there are fears that cash-poor, resource-rich countries will become trapped with considerable long-term debt, this issue is problematic. It is true that increasing national debt might cause social unrest, especially if a government would spend more on debt servicing than on other budget items. However, the lack of infrastructure is also a social and human rights issue, especially regarding essential public services like water and electricity. From our four cases, it is not possible to conclude that China is actively promoting inappropriate borrowing, instead it is likely that the increase in Chinese lending is demand-driven. Although the China Exim Bank is unlikely to fund any manifestly ludicrous project, it is the responsibility of the borrower (specifically the Parliament of any country) to ensure that there is a sound justification for any project.

The surge in the number of Chinese-constructed projects in Africa is not being driven by any excessive willingness on the part of the China Exim Bank to extend inappropriately cheap or unconditional finance. Instead, similar to the procedures and requirements of the export credit agencies of other countries, the China Exim Bank requires considerable use of Chinese goods (e.g., inputs) and services (e.g., construction firms) [132]. Furthermore, as evidenced by the Standard Gauge Railway, the China Exim Bank did require that there be proper compensation of project-affected people and a solid business case. It cannot be said that there are absolutely no strings attached to Chinese finance.

Cheap as Chinese loans may be in interest rate terms, they may actually be expensive since they prevent non-Chinese companies from being considered. Consequently, there tends not to be a competitive contractor selection process, thus potentially leading to higher pricing. The fact that most inputs must come from China deprives local companies of business opportunities, and does not address local unemployment. Since many governments are primarily concerned about their ability to access finance, there may not be proper scrutiny of development alternatives, construction plans, or of the environmental or social impacts of the proposed project. Use of Chinese finance and construction means that there is little local market stimulus, little local capacity building, and little regional multiplier effect. To prevent these negative outcomes, governments should carefully select contractors, closely supervise the quality of construction, and ensure compliance with international standards, especially in relation to project-induced displacement and resettlement [35,133-135].

China's development cooperation is motivated by a wide range of economic and diplomatic interests, including securing vital resources, opening-up new markets, widening investment opportunities, and forging new political alliances [136]. These interests are essentially the same as those of traditional Western lenders. Nevertheless, many observers (both Western and African), especially politicians and the media, are prone to recite simplistic themes about Chinese engagement with Africa [71,120-122,137,138].

Returning to the dilemma we posed in the Introduction to our paper, we suggest that resource-rich, cash-poor nations are not presented with a difficult choice, but with a relatively simple one. Should they delay construction of desired infrastructure until resource revenues eventuate in the future; borrow money now to build the infrastructure in the short term with the loans being repaid from future resource revenues (i.e., resourcefinanced infrastructure, RFI); or enter into a resources-for-infrastructure (R4I) deal in which a Chinese company builds the infrastructure now in exchange for resource concessions? The strong demand for infrastructure to spur development means that waiting is not desirable. China has only made R4I deals with a very few countries [139], obviously preferring the more normal RFI loans. With China having available capital to invest, and keen to use it to promote its products and services (as do the Exim banks of all countries), the choice for most borrowing countries is simple: China presents a better deal than the traditional lenders.

\section{Postscript}

Commercial oil deposits were discovered in Uganda in 2006. Initially, the oil fields were being developed by a joint venture involving Tullow Oil, Total, and CNOOC. At one 
stage, first oil (commencement of production) was expected in 2017, although this was later changed to 2020 and then to 2021. However, as at early March 2021, no final investment decision has yet been declared, although it is expected soon. There have been many delays to oil production, for a wide variety of reasons. In 2018, Tullow Oil decided to sell out to Total and CNOOC. However, the proposed sale created a dispute with the government about the amount of sales tax due. In August 2019 with no resolution to that dispute, the oil companies announced a stoppage of all work. In late 2019, the government backed down and only a modest tax was imposed. However, with a declining oil price, especially after the outbreak of the COVID-19 pandemic, work remained stalled for all of 2020. In early 2021, the oil companies recommenced work, but the first oil is still likely to be some years away. When the infrastructure projects discussed in this paper were conceived and the loans negotiated, it was presumed that the first repayments would not be due until after oil revenues had commenced. However, with the various delays to first oil, the grace periods will now expire years before any oil revenue is received by the Ugandan Government. Furthermore, the COVID-19 pandemic is likely to lead to a global economic downturn and to relatively low oil prices for some years, affecting the expected oil revenue to Uganda. Thus, Uganda will likely face a budget crisis over the next few years.

Author Contributions: Conceptualization, T.O. and F.V.; methodology, T.O.; formal analysis, T.O. and F.V.; investigation, T.O.; resources, F.V.; data curation, T.O.; writing-original draft preparation, T.O.; writing-review and editing, F.V.; supervision, F.V.; project administration, F.V.; funding acquisition, T.O. All authors have read and agreed to the published version of the manuscript.

Funding: This research was funded by a Nuffic Scholarship from The Netherlands Government.

Institutional Review Board Statement: The study was conducted according to the guidelines of the Declaration of Helsinki, and was approved by the Ethics Committee of Faculty of Spatial Sciences, University of Groningen, The Netherlands.

Informed Consent Statement: Informed consent was obtained from all participants involved in the research.

Data Availability Statement: The data presented in this study are available on reasonable request from the first author. The data are not publicly available because the qualitative interview data would reveal the identity of the research participants. All document sources are in the list of references.

Acknowledgments: The research was conducted with the assistance of Eunice Busisa. Nuwagira Upton produced Figure 1. Arjan van den Assem was also involved in the supervision of Tom Ogwang's PhD at the University of Groningen and commented on early drafts of this paper.

Conflicts of Interest: The authors declare no conflict of interest.

\section{References}

1. Ogwang, T.; Vanclay, F.; van den Assem, A. Impacts of the oil boom on the lives of people living in the Albertine Graben region of Uganda. Extr. Ind. Soc. 2018, 5, 98-103. [CrossRef]

2. Ogwang, T.; Vanclay, F.; van den Assem, A. Rent-seeking practices, local resource curse, and social conflict in Uganda's emerging oil economy. Land 2019, 8, 53. [CrossRef]

3. Ogwang, T.; Vanclay, F. Social impacts of land acquisition for oil and gas development in Uganda. Land 2019, 8, 109. [CrossRef]

4. Ogwang, T.; Vanclay, F. Cut-off and forgotten?: Livelihood disruption, social impacts and food insecurity arising from the East African Crude Oil Pipeline. Energy Res. Soc. Sci. 2021, 71, 101970. [CrossRef]

5. Van Alstine, J.; Manyindo, J.; Smith, L.; Dixon, J.; AmanigaRuhanga, I. Resource governance dynamics: The challenge of 'new oil' in Uganda. Resour. Policy 2014, 41, 48-58. [CrossRef]

6. Matsiko, H. Museveni badly needs \$20bn for big projects. The Independent. 19 September 2016. Available online: https: //www.independent.co.ug/museveni-badly-needs-20bn-big-projects / (accessed on 10 March 2021).

7. World Bank. Uganda UG Economic Update: Ninth Edition Infrastructure Finance Deficit: Can Public-Private-Partnerships Fill the Gap? World Bank: Washington, DC, USA, 2017; Available online: https://documents.worldbank.org/curated/en/261811498801726339 /pdf/P161699-06-30-2017-1498801724865.pdf (accessed on 10 March 2021).

8. Farooki, M. The infrastructure and commodities interface in Africa: Time for cautious optimism? J. Int. Dev. 2012, 24, 208-219. [CrossRef] 
9. Guasch, J. Granting and Renegotiating Infrastructure Concessions: Doing It Right; World Bank: Washington, DC, USA, 2004; Available online: https:/ / documents.worldbank.org/curated/en/678041468765605224/pdf/288160PAPER0Granting010renegotiating.pdf (accessed on 10 March 2021).

10. Van der Ploeg, L.; Vanclay, F.; Lourenço, I. The responsibility of business enterprises to restore access to essential public services at resettlement sites. In Socio-Economic Human Rights in Essential Public Services Provision; Hesselman, M., Hallo de Wolf, A., Toebes, B., Eds.; Routledge: Abingdon, UK, 2017; pp. 180-202.

11. Gil, N.; Stafford, A.; Musonda, I. (Eds.) Duality by Design: The Global Race to Build Africa's Infrastructure; Cambridge University Press: Cambridge, UK, 2019.

12. African Economic Outlook. African Economic Outlook. In Entrepreneurship and Industrialisation.; AfDB: Abidjan, Ivory Coast; OECD: Paris, France; UNDP: New York, NY, USA, 2017; Available online: https://www.afdb.org/fileadmin/uploads/afdb/ Documents /Publications / AEO_2017_Report_Full_English.pdf (accessed on 10 March 2021).

13. Collier, P.; Cust, J. Investing in Africa's infrastructure: Financing and policy options. Annu. Rev. Resour. Econ. 2015, 7, 473-493. [CrossRef]

14. Hallegatte, S.; Jun, R.; Julie, R. Lifelines: The Resilient Infrastructure Opportunity; World Bank: Washington, DC, USA, 2019; Available online: https: / / openknowledge.worldbank.org/handle/10986/31805 (accessed on 10 March 2021).

15. Foster, V.; Briceño-Garmendia, C.M. (Eds.) Africa's Infrastructure: A Time for Transformation; World Bank: Washington, DC, USA, 2009; Available online: https:/ / elibrary.worldbank.org/doi/abs/10.1596/978-0-8213-8041-3 (accessed on 10 March 2021).

16. Gutman, J.; Sy, A.; Chattopadhyay, S. Financing African Infrastructure: Can the World Deliver? Brookings Institution: Washington, DC, USA, 2015; Available online: https:/ /www.brookings.edu/wp-content/uploads/2016/07/AGIFinancingAfricanInfrastructure FinalWebv2.pdf (accessed on 10 March 2021).

17. Shen, W. China's role in Africa's energy transition: A critical review of its intensity, institutions, and impacts. Energy Res. Soc. Sci. 2020, 68, 101578. [CrossRef]

18. Alden, C. China and Africa: The relationship matures. Strateg. Anal. 2012, 36, 701-707. [CrossRef]

19. Alden, C.; Davies, M. A profile of the operations of Chinese multinationals in Africa. S. Afr. J. Int. Aff. 2006, 13, 83-96. [CrossRef]

20. Foster, V.; Butterfield, W.; Chen, C.; Pushak, N. Building Bridges: China's Growing Role as Infrastructure Financier for Sub-Saharan Africa; World Bank: Washington, DC, USA, 2009. [CrossRef]

21. Brautigam, D. Looking East: Africa's newest investment partners. Glob. J. Emerg. Mark. Econ. 2010, 2, 173-188. [CrossRef]

22. The Export-Import Bank of China. Available online: https:/ / english.eximbank.gov.cn (accessed on 10 March 2021).

23. China Development Bank. Available online: https://www.cdb.com.cn/English/ (accessed on 10 March 2021).

24. Sanfilippo, M. Chinese FDI to Africa: What is the nexus with foreign economic cooperation? Afr. Dev. Rev. 2010, 22, 599-614. [CrossRef]

25. Konijn, P.; van Tulder, R. Resources-for-infrastructure (R4I) swaps: A new model for successful internationalisation strategies of rising power firms? Crit. Perspect. Int. Bus. 2015, 11, 259-284. [CrossRef]

26. Davis, F.; Long, C.; Wabwire, M. Age of Choice: Uganda in the new Development Finance Landscape; Overseas Development Institute: London, UK, 2016; Available online: https:/ /www.odi.org/sites/odi.org.uk/files/resource-documents/10987.pdf (accessed on 10 March 2021).

27. Muchapondwa, E.; Nielson, D.; Parks, B.; Strange, A.; Tierney, M. ‘Ground-truthing' Chinese development finance in Africa: Field evidence from South Africa and Uganda. J. Dev. Stud. 2016, 52, 780-796. [CrossRef]

28. Brautigam, D.; Hwang, J.; Link, J.; Acker, K. Chinese Loans to Africa Database, China Africa Research Initiative; Johns Hopkins University School of Advanced International Studies: Washington, DC, USA, 2020; Available online: https://chinaafricaloandata. org/ (accessed on 10 March 2021).

29. van Marrewijk, A.; Clegg, S.R.; Pitsis, T.S.; Veenswijk, M. Managing public-private megaprojects: Paradoxes, complexity, and project design. Int. J. Proj. Manag. 2008, 26, 591-600. [CrossRef]

30. Flyvbjerg, B. What you should know about megaprojects and why: An overview. Proj. Manag. J. 2014, 45, 6-19. [CrossRef]

31. Ma, H.; Zeng, S.; Lin, H.; Chen, H.; Shi, J. The societal governance of megaproject social responsibility. Int. J. Proj. Manag. 2017, 35, 1365-1377. [CrossRef]

32. Vanclay, F. The potential contribution of social impact assessment to megaproject developments. In Socioeconomic Evaluation of Megaprojects: Dealing with Uncertainties; Lehtonen, M., Joly, P., Aparicio, L., Eds.; Routledge: Abingdon, UK, 2017 ; pp. 181-198.

33. Fazekas, M.; Tóth, B. Infrastructure for whom?: Corruption risks in infrastructure provision across Europe. In The Governance of Infrastructure; Wegrich, K., Kostka, G., Hammerschmid, G., Eds.; Oxford University Press: Oxford, UK, 2017 ; pp. 177-202.

34. Stevens, P.; Glada Lahn, G.; Kooroshy, J. The Resource Curse Revisited; Chatham House: London, UK, 2015.

35. Vanclay, F.; Hanna, P. Conceptualising company response to community protest: Principles to achieve a social license to operate. Land 2019, 8, 101. [CrossRef]

36. IMF. Guide on Resource Revenue Transparency; International Monetary Fund: Washington, DC, USA, 2005; Available online: https:/ / www.imf.org/external/pubs/ft/grrt/eng/060705.pdf (accessed on 10 March 2021).

37. Corkin, L. Chinese construction companies in Angola: A local linkages perspective. Resour. Policy 2012, 37, 475-483. [CrossRef]

38. Cheung, Y.; De Haan, J.; Qian, X.; Yu, S. China's outward direct investment in Africa. Rev. Int. Econ. 2012, 20, 201-220. [CrossRef]

39. Halland, H.; Beardsworth, J.; Land, B.; Schmidt, J. Resource Financed Infrastructure: A Discussion on a New Form of Infrastructure Financing; World Bank: Washington, DC, USA, 2014; Available online: https://documents.worldbank.org/curated/en/39437146 
8154490931/pdf/Resource-financed-infrastructure-a-discussion-on-a-new-form-of-infrastructure-financing.pdf (accessed on 10 March 2021).

40. Lin, J.; Wang, Y. New structural economics and resource financed infrastructure. Pac. Econ. Rev. 2016, 21, 102-117. [CrossRef]

41. Habiyaremye, A. Angola-mode trade deals and the awakening of African lion economies. Afr. Dev. Rev. 2013, $25,636-647$. [CrossRef]

42. Landry, D. The risks and rewards of resource-for-infrastructure deals: Lessons from the Congo's Sicomines agreement. Resour. Policy 2018, 58, 165-174. [CrossRef]

43. Maiza-Larrarte, A.; Claudio-Quiroga, G. The impact of Sicomines on development in the Democratic Republic of Congo. Int. Aff. 2019, 95, 423-446. [CrossRef]

44. Tam, C. Build-Operate-Transfer model for infrastructure developments in Asia: Reasons for successes and failures. Int. J. Proj. Manag. 1999, 17, 377-382. [CrossRef]

45. Kumaraswamy, M.; Zhang, X. Governmental role in BOT-led infrastructure development. Int. J. Proj. Manag. 2001, 19, 195-205. [CrossRef]

46. Sanderson, J. Risk, uncertainty and governance in megaprojects: A critical discussion of alternative explanations. Int. J. Proj. Manag. 2012, 30, 432-443. [CrossRef]

47. OECD. Public Integrity; Organization for Economic Cooperation and Development: Paris, France, 2017.

48. Gil, N.; Pinto, J. Polycentric organizing and performance: A contingency model and evidence from megaproject planning in the UK. Res. Policy 2018, 47, 717-734. [CrossRef]

49. Gwilliam, K. Africa's Transport Infrastructure: Mainstreaming Maintenance and Management; World Bank: Washington, DC, USA, 2011; Available online: https:/ / documents.worldbank.org/curated/en/728801468191665263/pdf/608030PUB0Afri10Box358 332B01PUBLIC1.pdf (accessed on 10 March 2021).

50. Hickey, S.; Izama, A. The politics of governing oil in Uganda: Going against the grain? Afr. Aff. 2017, 116, 163-185. [CrossRef]

51. Brautigam, D. China in Africa: What can Western Donors learn? Norwegian Investment Fund for Developing Countries: Oslo, Norway, 2011; Available online: https:/ / www.norfund.no/archive/Bilder/Publications/Norfund_China_in_Africa.pdf (accessed on 10 March 2021).

52. Alden, C. China in Africa. Survival 2005, 47, 147-164. [CrossRef]

53. Dollar, D. Understanding China's Belt and Road Infrastructure Projects in Africa; The Brookings Institution: Washington, DC, 2019; Available online: https://www.brookings.edu/wp-content/uploads/2019/09/FP_20190930_china_bri_dollar.pdf (accessed on 10 March 2021).

54. Hanauer, L.; Morris, L. Chinese Engagement in Africa: Drivers, Reactions, and Implications for U.S. Policy; Rand Corporation: Santa Monica, CA, USA, 2014.

55. Klare, M.; Volman, D. America, China \& the scramble for Africa's oil. Rev. Afr. Political Econ. 2006, 108, $297-309$.

56. Hongyi, H.L. China's oil diplomacy: Is it a global security threat. Third World Q. 2007, 28, 519-537.

57. Large, D. Beyond 'Dragon in the bush': The study of China-Africa relations. Afr. Aff. 2008, 107, 45-61. [CrossRef]

58. Alden, C.; Alves, C. China and Africa's Natural Resources: The Challenges and Implications for Development and Governance; South African Institute of International Affairs: Johannesburg, South Africa, 2009; Available online: https://saiia.org.za/wp-content/ uploads/2009/09/saia_sop_41_alden_alves_20090917.pdf (accessed on 10 March 2021).

59. Mlambo, C.; Kushamba, A.; Simawu, M. China-Africa relations: What lies beneath? Chin. Econ. 2016, 49, 257-276. [CrossRef]

60. Anyanwu, J.; Erhijakpor, A. Does oil wealth affect democracy in Africa. Afr. Dev. Rev. 2014, 26, 15-37. [CrossRef]

61. Van Wyk, J.; Dahmer, W.; Custy, M. Risk management and the business environment in South Africa. Long Range Plan. 2004, 37, 259-276. [CrossRef]

62. Mbabazi, P.K. The Oil Industry in Uganda: A Blessing in Disguise or an All too Familiar Curse? Nordic Africa Institute: Uppsala, Sweden, 2013.

63. Goumandakoye, H. Oil in Niger: A foundation for promise or a new resource curse? Extr. Ind. Soc. 2016, 3, 361-366. [CrossRef]

64. Isaksson, A.S.; Kotsadam, A. Chinese aid and local corruption. J. Public Econ. 2018, 159, 146-159. [CrossRef]

65. World Bank. Loan Handbook for World Bank Borrowers; World Bank: Washington, DC, USA, 2017.

66. Shaxson, N. Angola's homegrown answers to the 'resource curse'. In Governance of Oil in Africa: Unfinished Business; Lesourne, J., Ramsay, C.W., Eds.; Institut Français des Relations Internationales (IFRI): Paris, France, 2009; pp. 51-102.

67. Brautigam, D. Chinese development aid in Africa: What, where, why, and how much? In Rising China: Global Challenges and Opportunities; Golley, J., Song, L., Eds.; ANU EPress: Canberra, Australia, 2011; pp. 202-222. Available online: https: // press.anu.edu.au/node/395/download (accessed on 10 March 2021).

68. Asante, R. China and Africa: Model of South-South cooperation? China Q. Int. Strateg. Stud. 2018, 4, 259-279. [CrossRef]

69. Mohan, G.; Power, M. New African choices? The politics of Chinese engagement. Rev. Afr. Political Econ. 2008, 35, 23-42. [CrossRef]

70. Urban, F.; Nordensvard, J.; Siciliano, G.; Li, B. Chinese overseas hydropower dams and social sustainability: The Bui Dam in Ghana and the Kamchay Dam in Cambodia. Asia Pac. Policy Stud. 2015, 2, 573-589. [CrossRef]

71. Brautigam, D. The Dragon's Gift: The Real Story of China in Africa; Oxford University Press: New York, NY, USA, 2009.

72. Brautigam, D.; Gallagher, K. Bartering globalization: China's commodity-backed finance in Africa and Latin America. Glob. Policy 2014, 5, 346-352. [CrossRef] 
73. Tangri, R.; Mwenda, A. The Politics of Elite Corruption in Africa: Uganda in Comparative African Perspective; Routledge: Abingdon, UK, 2013.

74. Collier, P.; Kirchberger, M.; Söderbom, M. The Cost of Road Infrastructure in Low and Middle Income Countries; World Bank: Washington, DC, USA, 2015; Available online: https:/ / openknowledge.worldbank.org/bitstream/handle/10986/22664/The0 cost0of0ro0dle0income0countries.pdf (accessed on 10 March 2021).

75. Locatelli, G.; Mariani, G.; Sainati, T.; Greco, M. Corruption in public projects and megaprojects: There is an elephant in the room! Int. J. Proj. Manag. 2017, 35, 252-268. [CrossRef]

76. Eberhard, A.; Gratwick, K.; Morella, E.; Antmann, P. Independent Power Projects in Sub-Saharan Africa: Lessons from Five Key Countries; World Bank: Washington, DC, USA, 2016; Available online: https://openknowledge.worldbank.org/bitstream/ handle/10986/23970/9781464808005.pdf (accessed on 10 March 2021).

77. Jordana, J. Accountability challenges in the governance of infrastructure. In The Governance of Infrastructure; Wegrich, K., Kostka, G., Hammerschmid, G., Eds.; Oxford University Press: Oxford, UK, 2017; pp. 43-62.

78. Flyvbjerg, B. Five misunderstandings about case-study research. Qual. Inq. 2006, 12, 219-245. [CrossRef]

79. Yin, R.K. Case Study Research: Design and Methods, 4th ed.; Sage: Thousand Oaks, CA, USA, 2009.

80. Vanclay, F.; Baines, J.; Taylor, C.N. Principles for ethical research involving humans: Ethical professional practice in impact assessment Part I. Impact Assess. Proj. Apprais. 2013, 31, 243-253. [CrossRef]

81. China Exim Bank. White Paper on Green Finance; Export-Import Bank of China: Beijing, China, 2016. Available online: http: / / english.eximbank.gov.cn/News/WhitePOGF/ (accessed on 10 March 2021).

82. Ren, P.; Zhang, L.; Zhu, R.; Zhang, J. How China's Policy Banks can Support Sustainable Foreign Investment; Global Environmental Institute: Beijing, China, 2017; Available online: http://www.geichina.org/wp-content/uploads/2017/11/Sustainable_FDI_EN_ GEI2017.pdf (accessed on 10 March 2021).

83. Massa, I. Export Finance Activities by the Chinese Government; European Parliament Directorate-General for External Policies of the Union: Brussels, Belgium, 2011.

84. Brautigam, D.; Hwang, J. Great walls over African rivers: Chinese engagement in African hydropower projects. Dev. Policy Rev. 2019, 37, 313-330. [CrossRef]

85. Brautigam, D.; Hwang, J. Eastern Promises: New Data on Chinese Loans in Africa, 2000-2014; China-Africa Research Initiative, School of Advanced International Studies, Johns Hopkins University: Washington, DC, USA, 2016; Available online: https: // foreignpolicy.com/wp-content/uploads/2018/06/96909-easternpromisesv4.pdf (accessed on 10 March 2021).

86. Kirchherr, J.W.; Disselhoff, T.; Charles, K.J. Safeguards, financing, and employment in Chinese infrastructure projects in Africa: The case of Ghana's Bui Dam. Waterlines 2016, 35, 37-58. [CrossRef]

87. Global Environmental Institute. Comparing Financial Institutions' Environmental and Social Policies: Chinese and International Development Banks; Global Environmental Institute: Beijing, China, 2017; Available online: http://www.geichina.org/_upload/ file/report/Policy_Bank_1_pager_EN.pdf (accessed on 10 March 2021).

88. China Exim Bank. Export Buyer's Credit. Available online: http://english.eximbank.gov.cn/Business/CreditB/SupportingFT/ 201810/t20181016_6965.html (accessed on 10 March 2021).

89. China Exim Bank. Chinese Government Concessional Loan and Preferential Export Buyer's Credit (Two Concessional Facilities). Available online: http:/ / english.eximbank.gov.cn/Business/CreditB/SupportingFC/201810/t20181016_6972.html (accessed on 10 March 2021).

90. Uganda National Roads Authority. Kampala-Entebbe Expressway. Available online: https://www.unra.go.ug/kampala-entebbeexpressway-munyonyo- $51 \mathrm{~km} /$ (accessed on 1 October 2020).

91. Parliament of Uganda. Brief to Parliament on the Proposal to Borrow US \$350 Million from the Export-Import Bank of China, for Financing the Proposed Kampala-Entebbe Express Highway; Parliament of Uganda: Kampala, Uganda, 2011.

92. Twinoburyo, E. Uganda: When China's charming dragon bites, The Independent 20 September 2013. Available online: https: / /allafrica.com/stories/201309231444.html (accessed on 10 March 2021).

93. Buwembo, J. Uganda now has a genuine marvel for tourists to gape at: A \$500m road. The East African 24 November 2016. Available online: https:/ / www.theeastafrican.co.ke/oped/comment/Uganda-USD500m-Entebbe-Highway-most-expensiveroad/434750-3463078-bcync6/index.html (accessed on 10 March 2021).

94. Akello, J. Gov't to Start Repaying Entebbe Expressway Loan in July. Uganda Radio Network 26 April 2019. Available online: https:/ / ugandaradionetwork.net/story/govt-to-start-repaying-entebbe-expressway-loan-in-july- (accessed on 10 March 2021).

95. Mulindwa, H. Motorists cautioned as Kampala-Entebbe Expressway nears completion. Daily Monitor. 11 June 2019. Available online: https:/ / www.monitor.co.ug/Business/Prosper/Motorists-cautioned-Kampala-Entebbe-Expressway-nears-completion/ 688616-5151898-uh8vefz/index.html (accessed on 10 March 2021).

96. Gore, C. Electricity in Africa: The Politics of Transformation in Uganda; James Currey: Woodbridge, VA, USA, 2017.

97. Wesonga, N. Government delays release of Karuma funds. Daily Monitor, 9 June 2015.

98. Parliament of Uganda. Report of the Committee on National Economy on the Proposal by Government to Borrow Up to USD 1,435,158,862.48 from the Export-Import Bank of China to Finance the construction of the 600 MW Karuma Hydro Power Project and the Associated Interconnection Works Projects; Parliament of Uganda: Kampala, Uganda, 2015.

99. Nsereko, S. African Hand America Loves; Rose Dog Books: Pittsbugh, PA, USA, 2011. 
100. Kynge, J. Uganda turns east: Chinese money will build infrastructure says Museveni. Financial Times. 21 October 2014. Available online: https:/ / www.ft.com/content/ab12d8da-5936-11e4-9546-00144feab7de (accessed on 10 March 2021).

101. The Observer. Govt awards Karuma contract to Sinohydro. The Observer 20 June 2013. Available online: https: / / observer.ug/ component/content/article?id=25983: govt-awards-karuma-contract-to-sinohydro (accessed on 10 March 2021).

102. Atuhaire, A.; Akella, J. Questions over Karuma Dam. The Independent 4 October 2013. Available online: https://www.independent. co.ug/questions-karuma-dam/ (accessed on 10 March 2021).

103. Vokes, R. The politics of oil in Uganda. Afr. Aff. 2012, 111, 303-314. [CrossRef]

104. World Bank. Access to electricity (\% of population)_Uganda; World Bank: Washington, DC, USA, 2020; Available online: https: / / data.worldbank.org/indicator/EG.ELC.ACCS.ZS?locations=UG (accessed on 10 March 2021).

105. Parliament of Uganda. Report of the Committee on National Economy on the Proposal by Government to borrow up to USD $482,578,142.32$ from the Export-Import Bank of China to Finance the construction of the 183MW Isimba Hydro power Project and the Isimba Bujagali Interconnection Project; Parliament of Uganda: Kampala, Uganda, 2015. Available online: https://www.parliament.go.ug/cmis/ browser?id=780838eb-7c67-4920-abdb-bbe14b395f93\%3B1.0 (accessed on 10 March 2021).

106. Mbanga, J. Troubled Isimba Dam will miss 2018 launch deadline. The Observer 13 March 2017. Available online: https: / / observer.ug/businessnews/51734-troubled-isimba-dam-will-miss-2018-launch-deadline (accessed on 10 March 2021).

107. Matsiko, H. Chinese angry with Museveni. The Independent 7 November 2016. Available online: https:/ / www.independent.co. ug/chinese-angry-museveni/ (accessed on 10 March 2021).

108. Matsiko, H. The truth about Karuma, Isimba Mess. The Independent 25 April 2016. Available online: https://www.independent. co.ug/the-truth-about-karuma-isimba-mess/3/ (accessed on 10 March 2021).

109. Standard Gauge Railway. Available online: https:/ / www.sgr.go.ug/ (accessed on 10 March 2021).

110. Business Focus. Revealed: Why Uganda has delayed Standard Gauge Railway Project. Business Focus 22 September 2018. Available online: https:// businessfocus.co.ug/revealed-why-uganda-has-delayed-standard-gauge-railway-project/ (accessed on 10 March 2021).

111. Barigaba, J. SGR: Exim Bank rejects Uganda loan request again. The East African 7 March 2020. Available online: https:// www.theeastafrican.co.ke/business/SGR-Exim-Bank-rejects-Uganda-loan-request-again/2560-5482074-weyf6nz/index.html (accessed on 10 March 2021).

112. Miriri, D. Kenya opens $\$ 1.5$ billion Chinese-built railway linking Rift Valley town and Nairobi. Reuters 16 October 2019. Available online: https: / / www.reuters.com/article/ us-kenya-railway / kenya-opens-chinese-built-railway-linking-rift-valley-town-tonairobi-idUSKBN1WV0Z0 (accessed on 10 March 2021).

113. Asiimwe, D. China Exim sets terms for financing Uganda's Standard Gauge Railway. The East African 28 May 2016. Available online: https:/ / www.theeastafrican.co.ke/business/China-Exim-sets-terms-for-financing-Uganda-SGR/2560-3223214-esac0 $\mathrm{v}$ /index.html (accessed on 10 March 2021).

114. Taylor, I. Kenya's new lunatic express: The Standard Gauge Railway. Afr. Stud. Q. 2020, 19, $29-52$.

115. Parliament of Uganda. Report of the Physical Infrastructure Committee visit to the Ethiopia Standard Gauge Railway (SGR) and Light Rail Transit (LRT) Projects; Parliament of Uganda: Kampala, Uganda, 2016. Available online: https:/ /www.parliament.go.ug/ cmis/browser?id=cee1ffb4-7ec2-4f5e-a014-d703bbb7487c\%3B1.0 (accessed on 10 March 2021).

116. The Independent. Officials explain 'high' Standard Gauge Railway costs. The Independent 8 February 2017. Available online: https:/ / www.independent.co.ug/officials-explain-high-standard-gauge-railway-costs/ (accessed on 10 March 2021).

117. Uganda Ministry of Transport. Standard Gauge Railway (SGR) Project: Information about Standard Gauge Railway (SGR); Uganda Ministry of Transport: Kampala, Uganda, 2017. Available online: https://www.newvision.co.ug/digital_assets/d76bb012-a31c452d-adad-24df4d1931e5/SGR-fp-1.pdf (accessed on 1 October 2020).

118. PWC. Assessment of unit costs (standard prices) of rail projects (CAPital EXpenditure). European Commission: Brussels, Belgium, 2018. Available online: https:/ / ec.europa.eu/regional_policy/sources/docgener/studies/pdf/assess_unit_cost_rail_en.pdf (accessed on 10 March 2021).

119. Frick, K. The cost of the technological sublime: Daring ingenuity and the new San Francisco-Oakland Bay Bridge. In DecisionMaking on Mega-Projects; Priemus, H., Flyvbjerg, B., van Wee, B., Eds.; Edward Elgar: Cheltenham, UK, 2008 ; pp. $239-262$.

120. Brautigam, D. A critical look at Chinese 'debt-trap diplomacy': The rise of a meme. Area Dev. Policy 2020, 5, 1-14. [CrossRef]

121. Hirono, M.; Suzuki, S. Why do we need 'myth-busting' in the study of Sino-African Relations? J. Contemp. China $2014,23,443-461$. [CrossRef]

122. Singh, S. The myth of 'debt-trap diplomacy' and realities of Chinese development finance. Third World Q. 2020. [CrossRef]

123. Bank of Uganda. State of the Economy, September 2019; Bank of Uganda: Kampala, Uganda, 2019. Available online: https://www. bou.or.ug/bou/bouwebsite/bouwebsitecontent/publications/StateofEconomy/publications/StateOfEconomyReports/2019 /Sep/SOE-September-2019_Final-.pdf (accessed on 10 March 2021).

124. Wikipedia. List of countries by public debt. Available online: https://en.wikipedia.org/wiki/List_of_countries_by_public_debt (accessed on 10 March 2021).

125. Kasaija, M. Report on Public Debt, Guarantees, Other Financial Liabilities and Grants for Financial Year 2018/19; Uganda Ministry of Finance, Planning and Economic Development: Kampala, Uganda, 2019. Available online: https://www.finance.go.ug/sites/ default/files/Publications/REPORT\%20ON\%20PUBLIC\%20DEBT\%20GRANT\%202019.pdf (accessed on 10 March 2021). 
126. Govt borrowing is not sustainable. Daily Monitor 22 October 2020. Available online: https://www.monitor.co.ug/uganda/oped/ editorial/govt-borrowing-is-not-sustainable-2718506 (accessed on 10 March 2021).

127. Davis, A. China Funding Uganda's Kampala to Malaba Rail Network Project. Highways Today 20 January 2017. Available online: https: / / www.highways.today/2017/01/20/china-funding-ugandas-kampala-malaba-rail-network-project/ (accessed on 10 March 2021).

128. Matsiko, H. Workers dying at Chinese sites rise. The Independent. 12 December 2016. Available online: https://www.independent. co.ug/workers-dying-chinese-sites-rise/ (accessed on 10 March 2021).

129. Tan-Mullins, M.; Urban, F.; Mang, G. Evaluating the behaviour of Chinese stakeholders engaged in large hydropower projects in Asia and Africa. China Q. 2017, 230, 464-488. [CrossRef]

130. Alves, A. China's 'win-win' cooperation: Unpacking the impact of infrastructure-for-resources deals in Africa. S. Afr. J. Int. Aff. 2013, 20, 207-226. [CrossRef]

131. Blanchard, B.; Shepherd, C. China says its funding helps Africa develop, not stack up debt. Reuters World News 4 September 2018. Available online: https://www.reuters.com/article/us-china-africa/china-says-it-is-helping-africa-develop-not-pile-up-debtidUSKCN1LK0J6 (accessed on 10 March 2021).

132. Swedlund, H. Is China eroding the bargaining power of traditional donors in Africa? Int. Aff. 2017, 93, 389-408. [CrossRef]

133. Vanclay, F. Project induced displacement and resettlement: From impoverishment risks to an opportunity for development? Impact Assess. Proj. Apprais. 2017, 35, 3-21. [CrossRef]

134. Vanclay, F. Principles to gain a social licence to operate for green initiatives and biodiversity projects. Curr. Opin. Environ. Sustain. 2017, 29, 48-56. [CrossRef]

135. van der Ploeg, L.; Vanclay, F. A human rights based approach to project-induced displacement and resettlement. Impact Assess. Proj. Apprais. 2017, 35, 34-52. [CrossRef]

136. Buckley, P.; Clegg, L.; Cross, A.; Liu, X.; Voss, H.; Zheng, P. The determinants of Chinese outward foreign direct investment. J. Int. Bus. Stud. 2007, 38, 499-518. [CrossRef]

137. Plummer, A. Kenya and China's labour relations: Infrastructural development for whom, by whom? Africa 2019, 89, 680-695. [CrossRef]

138. Zongwe, D.P. Seven myths about Chinese migrants in Africa. Transnatl. Corp. Rev. 2015, 7, 480-493. [CrossRef]

139. Konijn, P. Chinese Resources-For-Infrastructure (R4I) Swaps: An Escape from the Resource Curse? South African Institute of International Affairs: Johannesburg, South Africa, 2014. 